\title{
Medicinal attributes of pyridine scaffold as anticancer targeting agents
}

\author{
Esraa Ali Mohamed ${ }^{1}$, Nasser S. M. Ismail ${ }^{2 *}$, Mohamed Hagras $^{3}$ and Hanan Refaat ${ }^{1}$
}

\begin{abstract}
Background: The heterocyclic compounds particularly pyridine displayed clinical and biological implementation. Pyridine scaffolds have been detected in most relevant drug molecules that included pyridine provided a great possibility for treatment.

Main text: Pyridine-containing compounds have increasing importance for medicinal application as antiviral, anticholinesterase activities, antimalarial, antimicrobial, antidiabetic and anticancer. This has generated concern among researchers in synthesising a variety of pyridine derivatives.

Conclusion: This review focuses on different pyridine targets as anticancer and their pharmacophoric elements controlling its activity.
\end{abstract}

Keywords: Pyridines, Anticancer, Cytotoxic action, Tyrosine kinases

\section{Background}

Pyridine is a basic heterocyclic organic compound; it is a bioisostere of benzene with one carbon displaced by a nitrogen atom. Also, it exhibited cytotoxic properties against tumour cells due to ortho-position at a nitrogen atom with the impact of methyl substitution on the pyridine ring in 4 or 5 positions. In recent research, it has relied on the synthesis of new anticancer agents targeting the tubulin-microtubule with heterocyclic rings. As Nicolaou et al. manifested cytotoxic properties in some lines of human cancer cells after he had synthesised pyridine epothilones [1]. Cancer is a group of more than 100 different diseases. It can develop almost anywhere in the body. The causes of cancers are host variables such as genetics, epigenetics, microbiome, age, gender, metabolic state, inflammatory state, and immune function. Environmental factors such as food contamination, viruses, UV radiation, carcinogens from the environment and diet/lifestyle factors as nutrients, energy consumption, phytochemicals, other food ingredients, alcohol,

\footnotetext{
* Correspondence: Nasser.mohamed@pharma.asu.edu.eg

${ }^{2}$ Faculty of Pharmacy, Department of Pharmaceutical Chemistry, Ain Shams University, Abbasia, Cairo, Egypt

Full list of author information is available at the end of the article
}

physical activity, and smoking. There are over 200 types of cancer: carcinoma, sarcoma, melanoma, lymphoma, and leukaemia. Globally, an estimated 9.6 million deaths were associated with cancer. in 2018. About one in six deaths worldwide were due to cancer. Approximately $22 \%$ of cancer deaths is because of tobacco [2]. The processes of carcinogenesis are initiation, promotion, and progression. Initiation is the first step in cancer development. In this stage, a genetic change is caused. Promotion is associated with a raised number of many daughter cells containing the mutation created in initiation. Progression is the last phase in process of carcinogenesis. It is characterised by increasing speed of growth that leads to building up of more genetic abnormalities contributing to the development of phenotype malignant invasive (Fig. 1) [3].

\section{Main text \\ Synthetic strategy \\ Synthetic approaches of pyridine are sufficiently well developed. It has been achieved by reaction of aceto- phenones and 1, 3 diamino propane which is cata- lysed by copper (a). This transformation providing 2- aryl pyridines [4]. Or 2-substituted pyridines were}




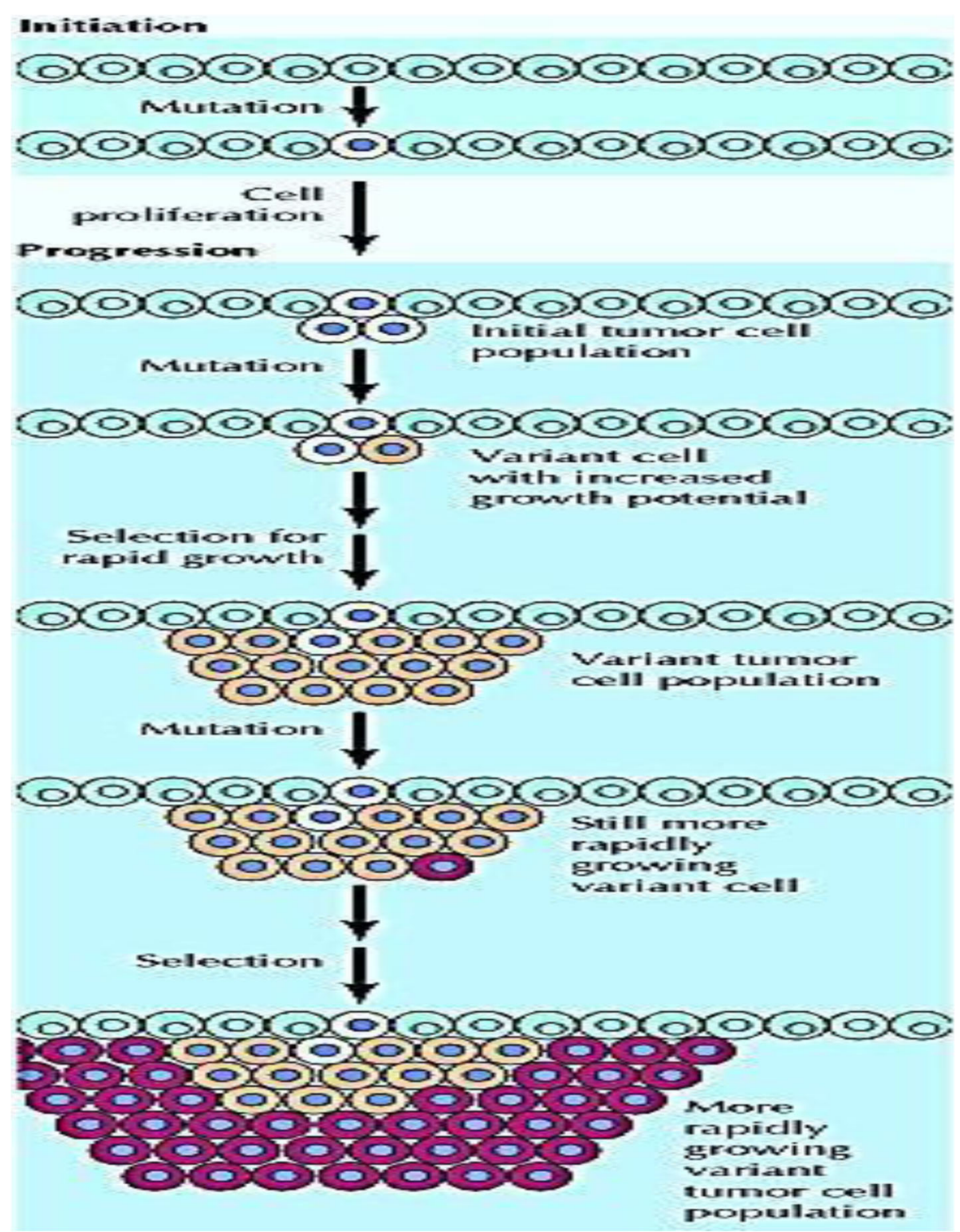

Fig. 1 Process of cancer development [3]

obtained by the addition of Grignard reagents to pyridine-N-oxides catalysed by THF at room temperature then treated by acetic anhydride at 120 ${ }^{\circ} \mathrm{C}$ provided 2-substituted pyridines (b) [5].

Also, pyridine can be obtained by Wittig reaction, Staudinger reaction, and Aza-Wittig reaction. As synthesis of polysubstituted pyridines from aldehydes, phousylides, and propargyl azide (c) [6] provided a wide range of polysubstituted dihydropyridine through lithiation/ isomeration/intramolecular carbolithiation (d) [7]. Coupling of silyl enol ethers with $\alpha, \alpha$-difluoro- $\beta$-iodoketones using fac-Ir (ppy) 3 under blue LED irradiation can be produced the substituted 3-fluoropyridines with subsequent one-pot condensation with ammonium acetate acetate (e) [8]. Synthesis of 3-hydroxyl pyridine derivatives can be achieved by olefin metathesis (RCM) (f) [9] Another method for synthesis of pyridine is an efficient base promoted reaction of 1 aryl ethyl amines with alkyne-ones gives enaminones under metal-free conditions to substituted pyridines (g) [10]. Highly substituted pyridines can be obtained by formal dehydrated ruthenium catalysed [ $4+2]$ cycloaddition of enamides and alkynes (h) [11]. In the presence of $\mathrm{Mn}(\mathrm{acac})_{3}$, reactions of vinyl azides with monocyclic cyclopropanols were produced pyridines. 2-Azabicyclo[3.3.1]non-2-en-1ol was produced from bicyclic cyclopropanols in the presence of a catalytic amount of $\mathrm{Mn}(\mathrm{acac}) 3$ (i) [12]. The combination of iodine and triethylamine activates a 2-aryl- 
substituted pyridine oxime-based synthesis with high chemo selectivity and strong functional group tolerance. Using this metal-free protocol, a wide variety of pyridines derivatives has been synthesised in high yields. Although this process cannot be caused by iodine or triethylamine, mechanistic experiments suggested a radical pathway (j) (Fig. 2) [12, 13].

This review focuses on the chemistry of pyridine derivatives, their potential activities as anticancer against various targets and their structure-activity relationship studies.

\section{Anticancer activity of pyridines}

\section{Pyridines acting on carbonic anhydrase inhibitors}

Carbonic anhydrase (CA) is a family of metalloenzymes that catalyses the interconversion of $\mathrm{CO} 2$ to $\mathrm{HCO}^{-}$and $\mathrm{H}^{+}$involved in the biocatalysing mineralisation process. It is one of the important enzymes that is found in red blood cells, gastric mucosa, pancreatic cells, and even renal tubules. It maintains acid-base balance, respiration, bone resorption, ureagenesis, gluconeogenesis, electrolyte secretion, and lipogenesis. CA isoenzymes are important therapeutic targets involved in these processes with the ability to be blocked for the treatment of a variety of diseases such as cancer. There are many relationships between CA and cancer [14]. In tumour cell, the transmembrane isoenzymes are CA IX and XII which are found predominantly in normal tissue with very limited amount and in tumour cells. The role of CA IX in cancer development links to hypoxia, acidosis, and beyond (Fig. 3) [15].

\section{Carcinoma in situ}

In growing tumour, CA keeps cancer cells from intracellular acidification and hypoxia through triggering extracellular acidosis. CA intercedes cancer cells' adhesion to vessels through producing acidosis that permits for transmigration to the lumen. Also, CA IX keeps cells from anoikis and ease extravasation to the site of secondary residence. CA IX can facilitate metastatic lesion by making focal adhesion and cell spreading. In primary tumours, CA IX has a role of expansion of metastasis by protecting cells from hypoxia and acidosis [16]. The new 4-(3, 4-dichlorophenyl)piperazine moiety compounds demonstrated inhibition of broad-spectrum growth in the $25-89 \%$ range across 26 cell lines. Compound 1 displayed the most potent inhibitor with standard inhibitor KI $=10.1 \mathrm{nM} \mathrm{[16].} \mathrm{Details} \mathrm{of} \mathrm{carbonic} \mathrm{anhydrase}$ inhibitory activity for compound 1 and normal human

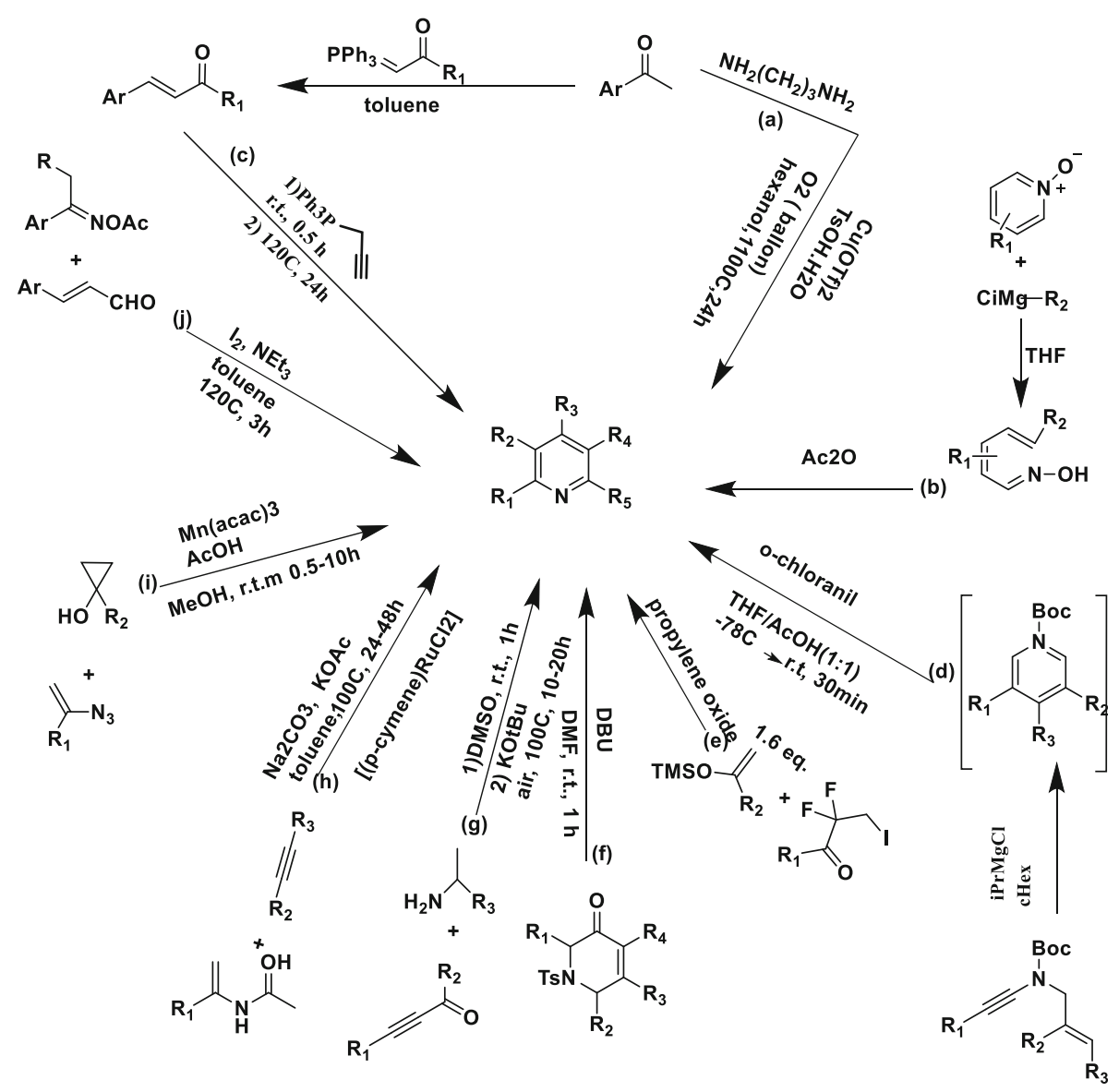

Fig. 2 Synthetic approaches for pyridines [13] 


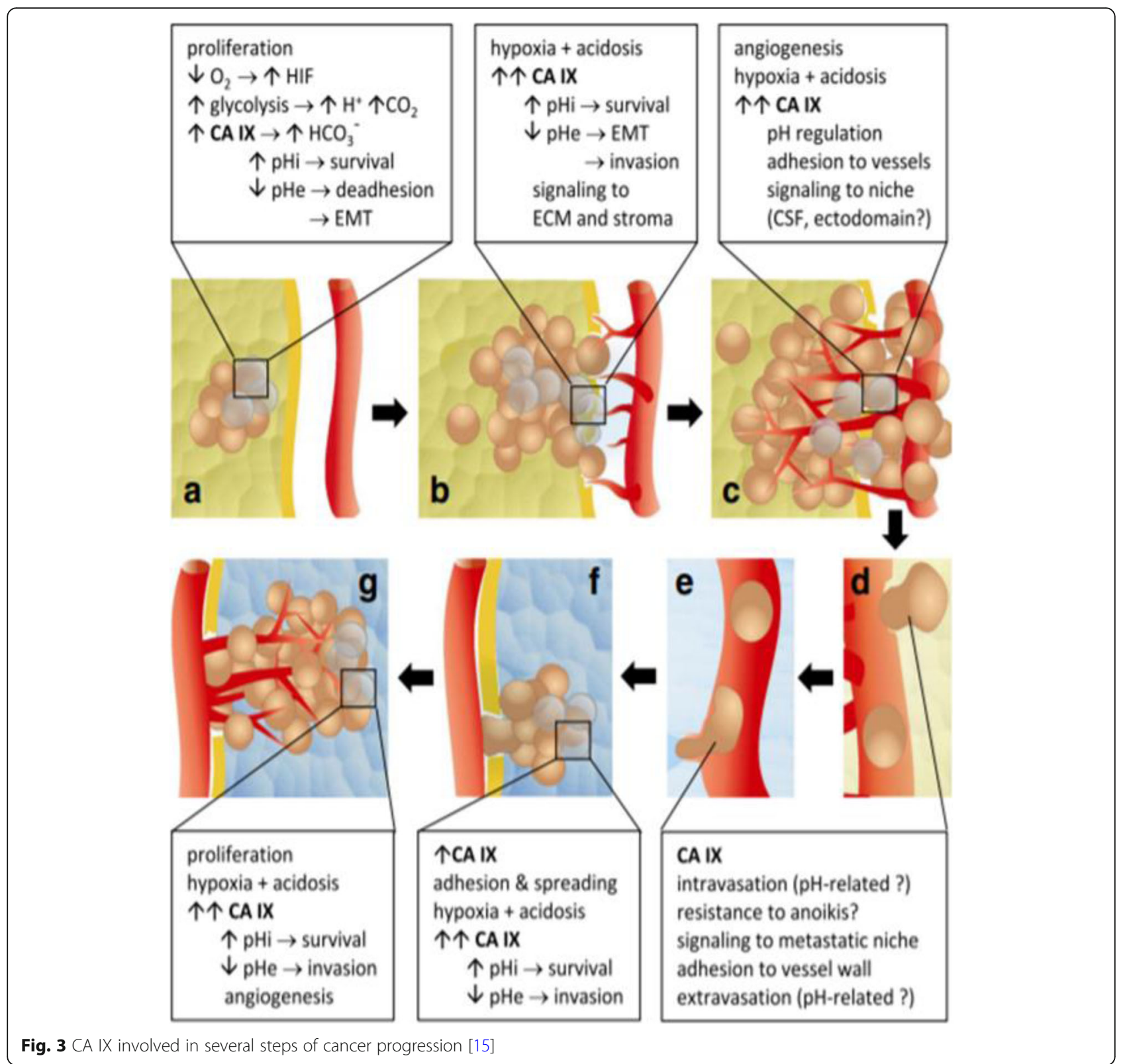

isoenzyme inhibitors hCA I, II, IX, and XII showed $7910 \mathrm{nM}, 85.5 \mathrm{nM}, 10.1 \mathrm{nM}$, and $93.4 \mathrm{nM}$, respectively.<smiles>COc1cc(N2CCN(C)CC2)ccc1C</smiles>

1

In 2017, Ansari et al. designed novel pyridinethiazolidinone derivatives which were evaluated as targeting human carbonic anhydrase IX. Compounds 2 and
3 were the most potent CAIX inhibitor with the $\mathrm{IC}_{50}$ value, $1.61 \mu \mathrm{M}$ and $1.84 \mu \mathrm{M}$, respectively. These have a significant binding with CAIX by $\mathrm{H}$-bonds and van der Waals interactions with active side residues. Also, these compounds revealed anti-cancer activity against HepG-2 with $\mathrm{IC}_{50}$ value $18.9 \pm 1.34 \mu \mathrm{M}$ and $16.2 \pm 1.34 \mu \mathrm{M}$. In addition, compounds 2 and 3 have shown selectivity for CAIX over CAII approximately 9 and 14 times, respectively [17]. Those two compounds have been tested against human CAII esterase activity with $\mathrm{IC}_{50} 14.44$ and 27.18. Compounds 2 and 3 showed approximately 9 and 14 times selectivity for CAIX over CAII, respectively. 
<smiles>O=C1/C(=C\c2ccc([N+](=O)[O-])cc2)S/C(=N/c2ccccc2)N1Cc1ccncc1</smiles><smiles>O=C1/C(=C/c2ccc(O)c(O)c2)S/C(=N/c2ccccc2)N1Cc1ccncc1</smiles>

Pyridine-thiazolidinone derivatives' structure-activity relationship explained the compounds containing phenyl ring 3 without substitution and phenyl ring substitution of the alkyl group. Excellent inhibitory activity against CAIX with IC50 $=1.61 \mu \mathrm{M}$ compound with nitro substitution on benzene ring 8. SAR showed that 7 had an excellent effect on the behaviour of CAIX inhibition in compounds with hydroxyl groups. Excellent CAIX $\left(\mathrm{IC}_{50}=1.84 \mu \mathrm{M}\right)$ was present in compound 2 with the di-hydroxyl group. It can be surmised on the basis of SAR studies that the compounds containing polar moieties 2 and 3 on the phenyl ring are ideal for excellent inhibitory action against CAIX. Furthermore, the inhibition of CAIX by a single compound does not depend solely on the presence of the substituents but is essential as a whole molecular skeleton for its purpose. In 2018, Peerzada et al. introduced tertiary sulfonamide derivatives of pyridyl-indolebased heteroaryl chalcone as carbonic anhydrase IX inhibitors and anticancer agents. Compounds $4 \mathrm{a}, 4 \mathrm{~b}$, and $4 \mathrm{c}$ showed inhibitory the CA IX selectively $\left(\mathrm{IC}_{50}: 4 \mathrm{a}=0.15 \mu \mathrm{M}\right.$, $4 \mathrm{~b}=0.13 \mu \mathrm{M}$, and $4 \mathrm{c}=0.15 \mu \mathrm{M})$. They have a better binding affinity. Moreover, they possessed predominant antiproliferative potential and prompted apoptosis in MCF-7 cells with values in $41.75 \%, 89.33 \%$, and $21.57 \%$ of cells, respectively (Table 1 ). Also, they have anti-tumour evaluation against HepG-2 cell lines in vitro. Thus, it can be explained that the activity of these compounds is substituent dependent [18].<smiles>[R]S(=O)(=O)n1cc(/C=C/C(=O)c2ccncc2)c2ccccc21</smiles>

4

\section{Pyridines acting on ROS1 inhibitors}

Proto-oncogene tyrosine protein kinase (ROS) is an enzyme encoded in humans by the ROS 1 gene. It has an anaplastic lymphoma kinase protein (ALK) structural similarity. Like normal physiological ligands, ROS1 plays

Table 1 Biological activity of the compounds (4a-c) against various cell lines

\begin{tabular}{|c|c|c|c|c|c|}
\hline $\begin{array}{l}\text { Compound } \\
\text { No. }\end{array}$ & $\mathrm{R}$ & $\begin{array}{l}\text { HEK-293 } \\
\mathrm{IC}_{50} \\
(\mu \mathrm{M}) \pm \text { S.D. }\end{array}$ & $\begin{array}{l}\text { MCF7 } \\
\mathrm{IC}_{50} \\
(\mu \mathrm{M}) \pm \text { S.D. }\end{array}$ & $\begin{array}{l}\text { HepG-2 } \\
\mathrm{IC}_{50} \\
(\mu \mathrm{M}) \pm \text { S.D. }\end{array}$ & $\begin{array}{l}\text { Esterase } \\
\text { assay IC } 50 \\
(\mu \mathrm{M}) \\
\text { hCA IX }\end{array}$ \\
\hline $4 a$ & & $150>$ & $24.0 \pm 1.16$ & 0.15 & $27 \pm 1.67$ \\
\hline $4 b$ & & $150>$ & $48.9 \pm 1.19$ & 29.9 & $44.8 \pm 1.35$ \\
\hline $4 c$ & & $150>$ & $14.5 \pm 1.15$ & 0.15 & $18.3 \pm 1.44$ \\
\hline
\end{tabular}


a role in normal development. In 2018, novel 2-amino-4-(1phenylethoxy) pyridine derivatives have been synthesised by Tian et al. as possible ROS1 inhibitors with 1-phenylethoxy at positions $\mathrm{C}-3$ and $\mathrm{C}-4$. Anti-proliferative effects against ROS1-addicted HCC78 cell lines with $\mathrm{IC}_{50}$ values of $8.1 \mu \mathrm{M}$ and $65.3 \mu \mathrm{M}$ were demonstrated by the tested compounds, $5 \mathrm{a}$ and $5 \mathrm{~b}$. In addition, they showed the most inhibitory behaviour of ROS1, values of $\mathrm{IC}_{50}(440-370 \mathrm{nM})$. Related binding poses were shared with crizotinib, except for the selective binding site of ROS1 (Table 2) [19]. Specifically, the 1phenylethoxy substitution of the 2-amino-pyridine ring at position C-4 showed greater activity than that at position C3 . One of the 2-NH2 hydrogen atoms, replaced by the hydrophilic group, would favour action in group R1. Of the substitution groups, the optimal group was 1-(piperidin-4yl)-1H-pyrazol-4-yl followed by 1-(1-methylpiperidin-4-yl)$1 \mathrm{H}$-pyrazol-4-yl and followed by 1-(1-methylpiperidin-4-yl)1H-pyrazol-4-yl. ROS1 activities were relatively small, whereas other heterocyclics and benzenes were present in R1. For the R2 group, the methoxy groups on the benzene ring of synthesised compounds were in favour of the action. 3,4,5-Trimethoxyl was the optimal group for these groups, followed by 3,4-dimethoxyl, 3-methoxyl, 4-methyl, and 4-CN

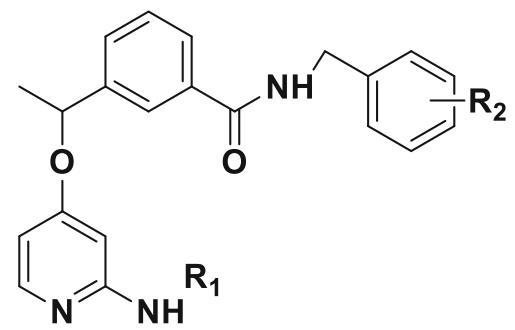

5

\section{Pyridines acting as ALK/ROS1 dual inhibitors}

In 2019, Liu et al. discovered 2-amino-4-(1-piperidine) pyridine derivatives as novel anti-crizotinib-resistant ALK/ROS1 dual inhibitors. A novel DFG-shifted conformation in the kinase domain of ALK was planned to stabilise it. Compound 6 replaced para-trifluoromethoxy at R2 with not only potent inhibitory activity approximately 6-fold over crizotinib ( $\mathrm{IC}_{50}: 104.7 \mathrm{nM}$ vs. 643.5 $\mathrm{nM}$ ) in ROS1G2032R harbouring $\mathrm{Ba} / \mathrm{F} 3$ cell line, but also anti-proliferative activity against ALK-addicted $\mathrm{H} 3122$ and ROS1-addicted HCC78 cell lines ( $\mathrm{IC}_{50}$ : $6.27 \mu \mathrm{M}$ and $10.71 \mu \mathrm{M}$, respectively). Also, interestingly, enzyme activity versus clinically crizotinib-resistant ALKL1196 M with an IC50 value of $41.3 \mathrm{nM}$ was reported, which was approximately twice as potent as crizotinib. In addition, compound 8 showed an $\mathrm{IC}_{50}$ inhibitor of ROS1 with a value of $1.08 \mu \mathrm{M}$ (Table 3) [19, 20]. The favoured group, oddly, was paratrifluorometoxy. By increasing the electron density, electron-donating substituents had been lightened.

Cloud on the ring of benzene strengthened the ligandreceptor interaction (Fig. 4). A 2-methoxy-4-(piperazine1-yl) substituent was adequate in the compound 6 study. SAR has shown that the electron-donating substituent is better than one at position R2.<smiles>[R]Nc1cc(N2CCCC(C(=O)NCc3ccc([R])cc3)C2)ccn1</smiles>

6

Table 2 Inhibitory activity of the compounds 5a and 5b kinase activities and in vitro antiproliferative effects

\begin{tabular}{|c|c|c|c|c|c|c|}
\hline Compd. & R1 & R2 & $\begin{array}{c}\text { Kinase } \\
\text { activities } \\
\text { ALK }\end{array}$ & $\begin{array}{c}\text { Inhibitory } \\
\text { IC }_{50} \\
(\mu \mathrm{M}) \\
\text { ROS1 }\end{array}$ & $\begin{array}{c}\text { In vitro } \\
\text { antiproliferative } \\
\text { effects IC50 } \\
(\mu \mathrm{M}) \\
\text { H3122 }\end{array}$ & HCC78 \\
\hline $5 \mathrm{a}$ & & $\begin{array}{c}3.4- \\
\text { di- } \\
\text { OMe }\end{array}$ & 4.5 & 0.37 & 47.2 & 65.3 \\
\hline $5 b$ & $4-\mathrm{Me}$ & 3.1 & 0.44 & 8.9 & 8.1 \\
\hline
\end{tabular}


Table 3 The kinase inhibitory activities and in vitro anti-proliferative effects of target compounds

\begin{tabular}{|c|c|c|c|c|c|c|c|c|c|}
\hline \multirow{3}{*}{$\begin{array}{l}\text { Compo } \\
\text { und }\end{array}$} & \multirow[t]{3}{*}{ R1 } & \multirow[t]{3}{*}{$\mathrm{R} 2$} & \multicolumn{4}{|c|}{ Enzyme activity } & \multicolumn{3}{|c|}{ Cellular activity $(\mu \mathrm{M})$} \\
\hline & & & \multicolumn{2}{|l|}{ ALK } & \multicolumn{2}{|l|}{ ROS1 } & \multirow{2}{*}{$\begin{array}{l}\text { HCC- } \\
78\end{array}$} & \multirow{2}{*}{$\begin{array}{l}\mathrm{H} 312 \\
2\end{array}$} & \multirow[t]{2}{*}{ A549 } \\
\hline & & & $\begin{array}{l}\text { Inhibitio } \\
\mathrm{n}(\mu \mathrm{M})\end{array}$ & $\begin{array}{l}\text { IC50( } \\
\mu \mathrm{M})\end{array}$ & $\begin{array}{l}\text { Inhibitio } \\
\mathrm{n}(\mu \mathrm{M})\end{array}$ & $\begin{array}{l}\text { IC50( } \\
\mu \mathrm{M})\end{array}$ & & & \\
\hline $6 a$ & & $\begin{array}{l}4- \\
\text { OCF3 }\end{array}$ & $90 \%$ & 0.492 & $75 \%$ & 1.08 & $\begin{array}{l}14.94 \\
\pm 4.71\end{array}$ & $\begin{array}{l}7.53 \pm \\
0.72\end{array}$ & $\begin{array}{l}7.79 \pm 3 . \\
63\end{array}$ \\
\hline $6 \mathrm{~b}$ & & $\begin{array}{l}4- \\
\text { OCF3 }\end{array}$ & $95 \%$ & 0.174 & $88 \%$ & 0.530 & $\begin{array}{l}10.71 \\
\pm 2.30\end{array}$ & $\begin{array}{l}6.45 \pm \\
2.90\end{array}$ & $\begin{array}{l}3.64 \pm 1 . \\
27\end{array}$ \\
\hline
\end{tabular}

\section{Pyridines acting on c-Met}

The receptor tyrosine kinase (RTK) c-Met is protein that termed the hepatocyte growth factor (HGF) receptor and encoded by a MET gene [22]. Zhao et al. discovered some pyridine scaffolds as type II c-Met inhibitors. C-met has pivotal cascades in formation, dissemination, and progression of many types of cancers, in addition to resistance. Stimulation of HGF is observed repeatedly in different human cancers. So, cMet has characters that make it a remarkable target for cancer treatment. Compound 7 that holds 4fluorophenyl substitution displayed potent c-Met inhibitory potency with $\mathrm{IC}_{50}=12$. Nitrogen-containing aromatic rings in compound 7 minimise both VEGFR inhibitory activities and side effects. Finally, this compound exhibited both an acceptable kinase selectivity profile and anti-proliferative activity $\left(\mathrm{IC}_{50}=127 \mathrm{nM}\right.$ against EBC-1 cell line) [21].<smiles>Nc1nccc(Oc2ccc(NC(=O)C3(C(=O)Nc4ccc(F)cc4)CC3)cc2F)c1Cl</smiles>

Wang et al.'s rational design in 2018 leads to the discovery of a novel and potent sequence of $1 \mathrm{H}$-pyrrolo [2, 3b] pyridine derivatives as c-Met inhibitors carrying aromatic hydrazone moiety. Many of the latest compounds tested for the $\mathrm{IC}_{50}$ values against cancer cell lines (A549, HepG2, MCF-7, and PC-3). Also, these compounds showed perfect cytotoxicity activity. Further, they can trigger apoptosis of A549 cells and arrest worthily the cell cycle progression in $G 2 / \mathrm{M}$

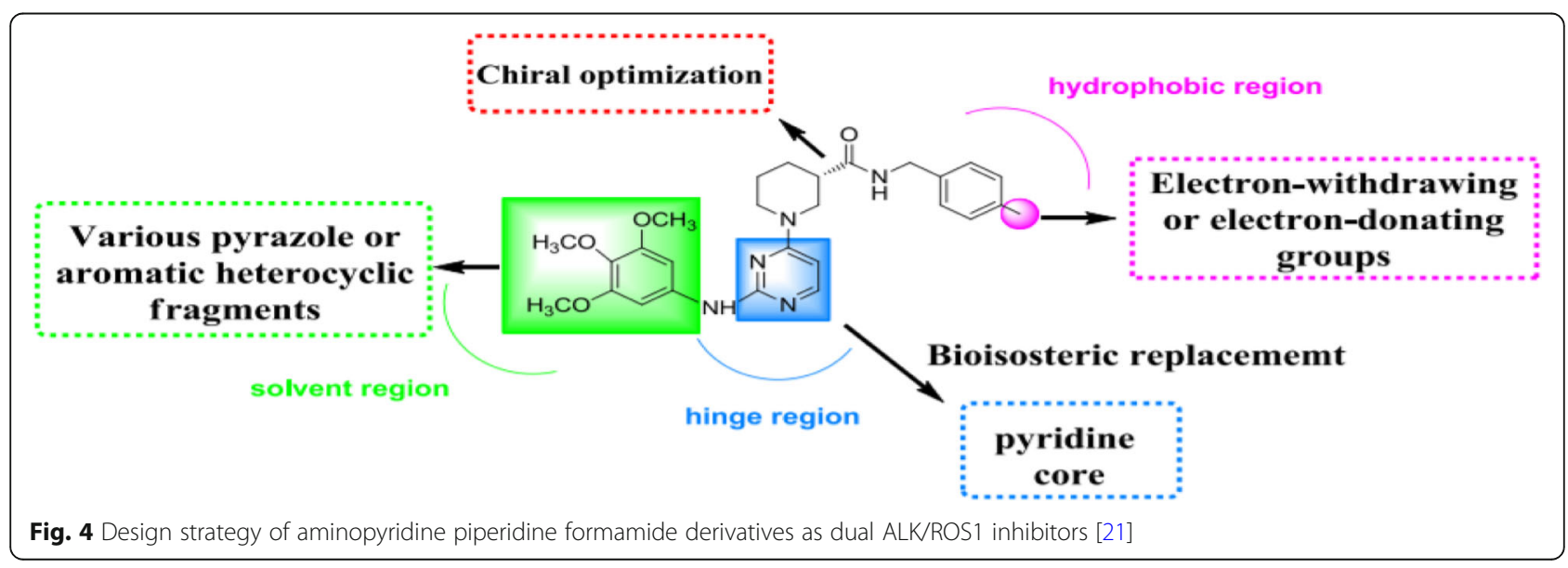


phase of A549 cells. Two compounds 8 and 9 were further profiling against c-Met kinase in vitro. An ATP mobility change assay with reference compound Foretinib (Table 4) [23].

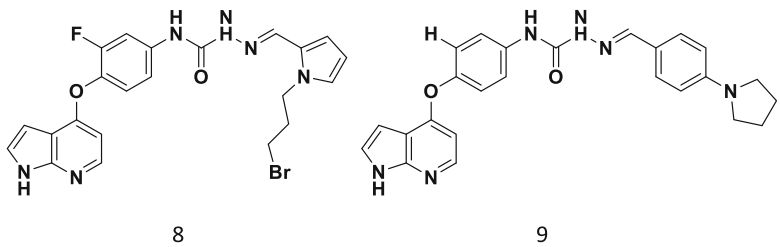

Molecular docking simulation studies were achieved for compound 8 . The 3D and 2D graph were depicted, and the hydrogen was coloured with green, the pi-pi stacked bond was coloured with blue, and the halogen was coloured with pink (Fig. 5).

\section{Pyridines acting on EGFR}

Epidermal growth factor receptor is a transmembrane receptor that has a vital role in cell proliferation, survival, differentiation, and migration [25]. Also, it is carrying out both redundant and restricted functions in development. It contains an extracellular binding site for the domains of epidermal growth factors (EGF) and intracellular tyrosine kinase. Many human diseases especially cancer results from misregulation of EGFR. So, inhibiting this pathway has proven as an efficient cancer treatment (Fig. 6).

An extended conformation resulting from ligand binding induces kinase domain dimerisation and activation. ATP binding site is formed by the kinase loops of the $\mathrm{C}$ - and $\mathrm{N}$-terminals. The $\mathrm{X}$-ray structures demonstrate that the affinity of inhibitors for the binding site originates from hydrogen, bonding to the main chain between the $\mathrm{N}-1$ of pyrimidine, $\mathrm{NH}$ from Met793. For AEE-788, an association between hydrogen bonds between $\mathrm{N}$ - and Thr854, bridged water was observed through water molecules [26].

Potent and novel 3,4 Diaryl $1 \mathrm{H}$ pyrrolo[2,3 b] pyridines scaffolds were introduced for use as irreversible inhibitors of mutant EGFR L858R/T790M through scrutinise the effect of different aromatic substituents in the 4 position that introduced by using either Suzuki or Buchwald-Hartwig cross-

Table 4 Action against c-Met kinase inhibitory of selected compounds 8 and 9

\begin{tabular}{ll}
\hline Compounds & $\mathbf{I C}_{\mathbf{5 0}}(\mu \mathrm{M})$ \\
\hline & C-Met \\
9 & 0.506 \\
Foretinib & 0.907 \\
\hline
\end{tabular}

coupling reactions. Compound 10c exhibited the most potent in the gefitinib resistant EGFR-L858R/ T790M enzyme assay and selectivity over the wild type. It was reported that compounds $10 \mathrm{a}$ and $10 \mathrm{~b}$ showed the most selective compounds over 10-fold selectivity for the mutant enzyme over the wild type. It can conclude the importance of electron-rich heterocycles in the activity of compounds $10 \mathrm{a}$ and $10 \mathrm{~b}$. Moreover decoration of the $1 \mathrm{H}$-pyrrolo[2,3-b]pyridine with indol-3-yl substituents in compound $10 \mathrm{c}$ lead to improve the activity (Table 5) [27].<smiles>[R]c1ccnc2[nH]cc(-c3cccc(NC(=O)C=C)c3)c12</smiles>

10

\section{Pyridines acting as EGFR and HER-2 kinase inhibitors}

EGFR family includes EGFR (HER1/ErbB-1), ErbB-2 (HER2/neu), ErbB-3 (HER3), and ErbB-4 (HER4) [27]. HER2 (human epidermal growth factor receptor 2) is a gene that has had breast cancer connection. It recently employs around $30 \%$ of breast cancer patients as an effective biomarker and therapy target. It plays a vital role in tumour development and progression. On the contrary, Sanganiet al. unmasked new class of potential EGFR and HER-2 kinase inhibitors possessing biquinoline-pyridine hybrids which intended by a base-catalysed cyclo condensation through one-pot multicomponent reaction [27]. The most outstanding activity as dual EGFR and HER-2 inhibitors was laboured by compound 11 with $\mathrm{IC}_{50}=$ $0.09 \mu \mathrm{M}$ against EGFR and HER-2 kinase with $\mathrm{IC}_{50}=$ $0.2 \mu \mathrm{M}$. Molecular modelling study showed the binding mode by four hydrogen bonds and two $\mathrm{p}-$ cation interactions with the effective pocket of EGFR (Fig. 7). The binding energy DGb $=54.4 \mathrm{kcal} / \mathrm{mol}$.<smiles>CCOC(=O)C1=C(N)N(c2cccnc2)C2=C(C(=O)CCC2)C1C1=CC2C=CC=CC2n2nnnc21</smiles>

11

Structure-activity relationship depends both the heteroaromatic bicyclic revealed that the activity in deceasing 


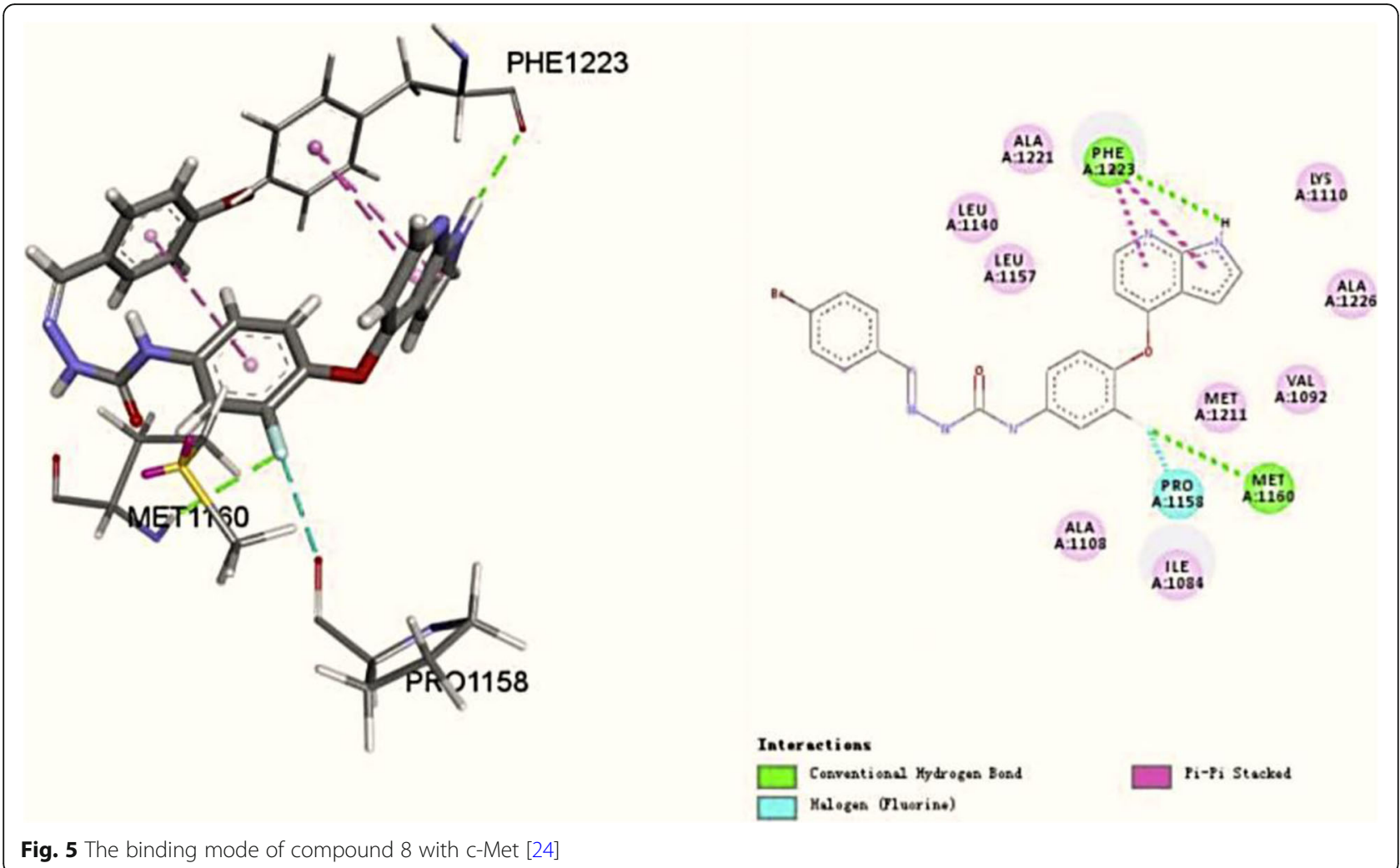

order for $\mathrm{R} 1$ substitution is $\mathrm{H}>\mathrm{OCH} 3>\mathrm{CH} 3>\mathrm{Cl}$ and for $\mathrm{R} 2$ substitution is COOEt $>\mathrm{COOMe}>\mathrm{CN}$ for EGFR and HER-2 kinase inhibitors. But the activity in deceasing order for $\mathrm{R} 1$ substitution is $\mathrm{Cl}>\mathrm{H}>\mathrm{CH} 3>\mathrm{OCH} 3$ and for $\mathrm{R} 2$ substitution is COOMe $>\mathrm{COOEt}>\mathrm{CN}$ for cancer cell lines A549 and Hep G2 [27].

\section{Pyridines as cyclin-dependent kinase (CDK) inhibitor}

CDKs are a set of serine/threonine kinases. They control the eukaryotic cell cycle by their function in cell growth, development, proliferation, and death. They are answerable for the cell cycle's coincidence. CDKs, with their partner subunit cyclin, take responsibility for the

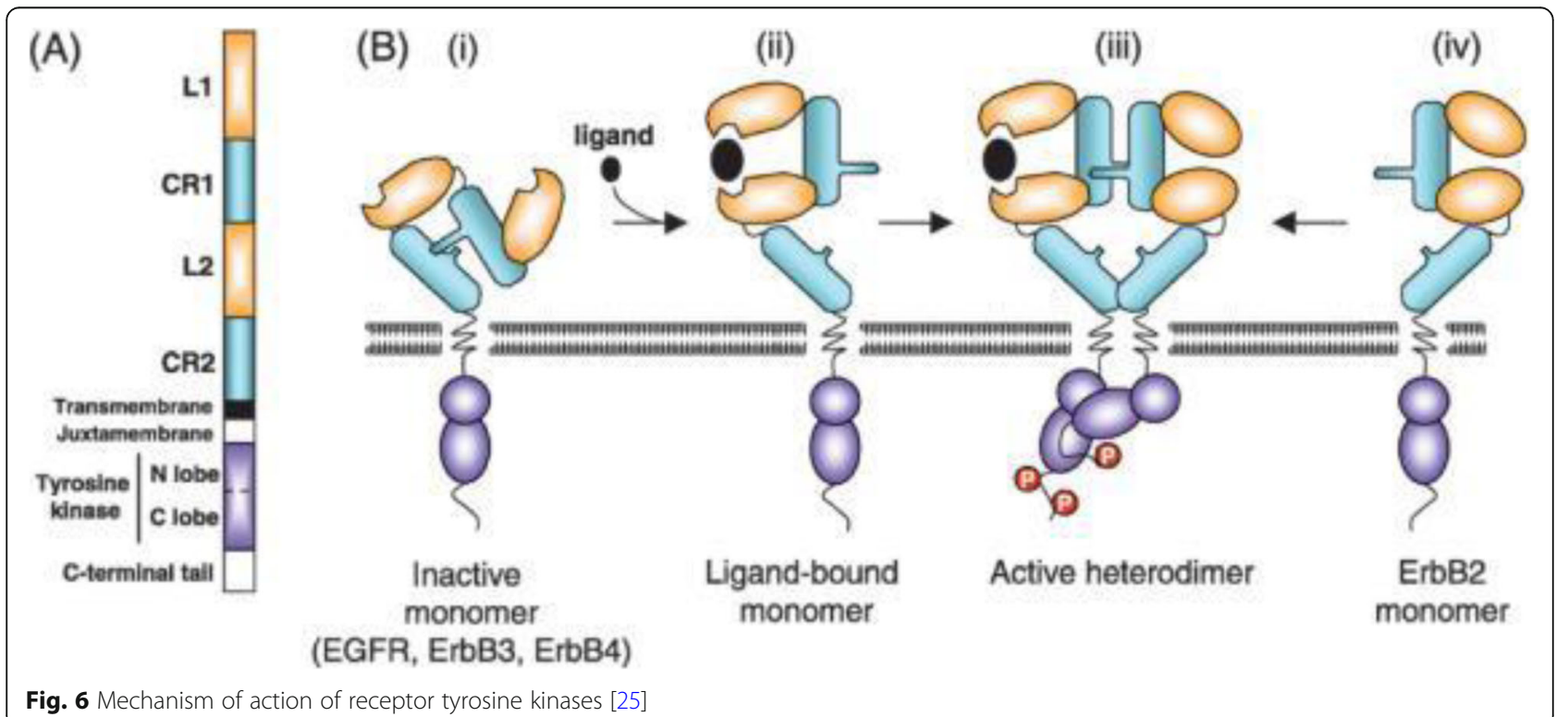


Table $\mathbf{5} \mathrm{IC}_{50}$ values in an EGFR-L858R/T790M kinase assay

\begin{tabular}{|l|l|l|}
\hline No. & $\begin{array}{l}\text { IC } 50 \text { EGFR- } \\
\text { L858R/T790M }(\mu \mathrm{M})\end{array}$ \\
\hline $10 \mathrm{a}$ & 0.198 \\
\hline $10 \mathrm{~b}$ & & \\
\hline $10 \mathrm{c}$ & & 0.027 \\
\hline
\end{tabular}

harmonisation of the event series by cell progression occuring during the cell cycle. At particular levels, they become effective. They turned into active at specific phases: G1, S, G2, and M. CDK9 is a transcriptional regulator that controls the expression in cancer cells of anti-apoptotic proteins that enforce immortality. It interacts with many transcription variables (TFs) and regulates their operations. By attacking both androgen receptor activity and anti-apoptotic proteins, CDK9 inhibitors can supply a novel and greater therapeutic scope over conventional treatment choice [28, 29]. Nada et al. recently designed and synthesised of novel imidazo[4,5b]pyridine based compounds as cyclin-dependent kinase 9. In a particular way, compounds 12 and 13 were the most active compounds $\mathrm{CDK} 9$ enzyme assay $\left(\mathrm{IC}_{50}=\right.$ $0.50-1.002 \mu \mathrm{M})$. In addition, compound 12 found the
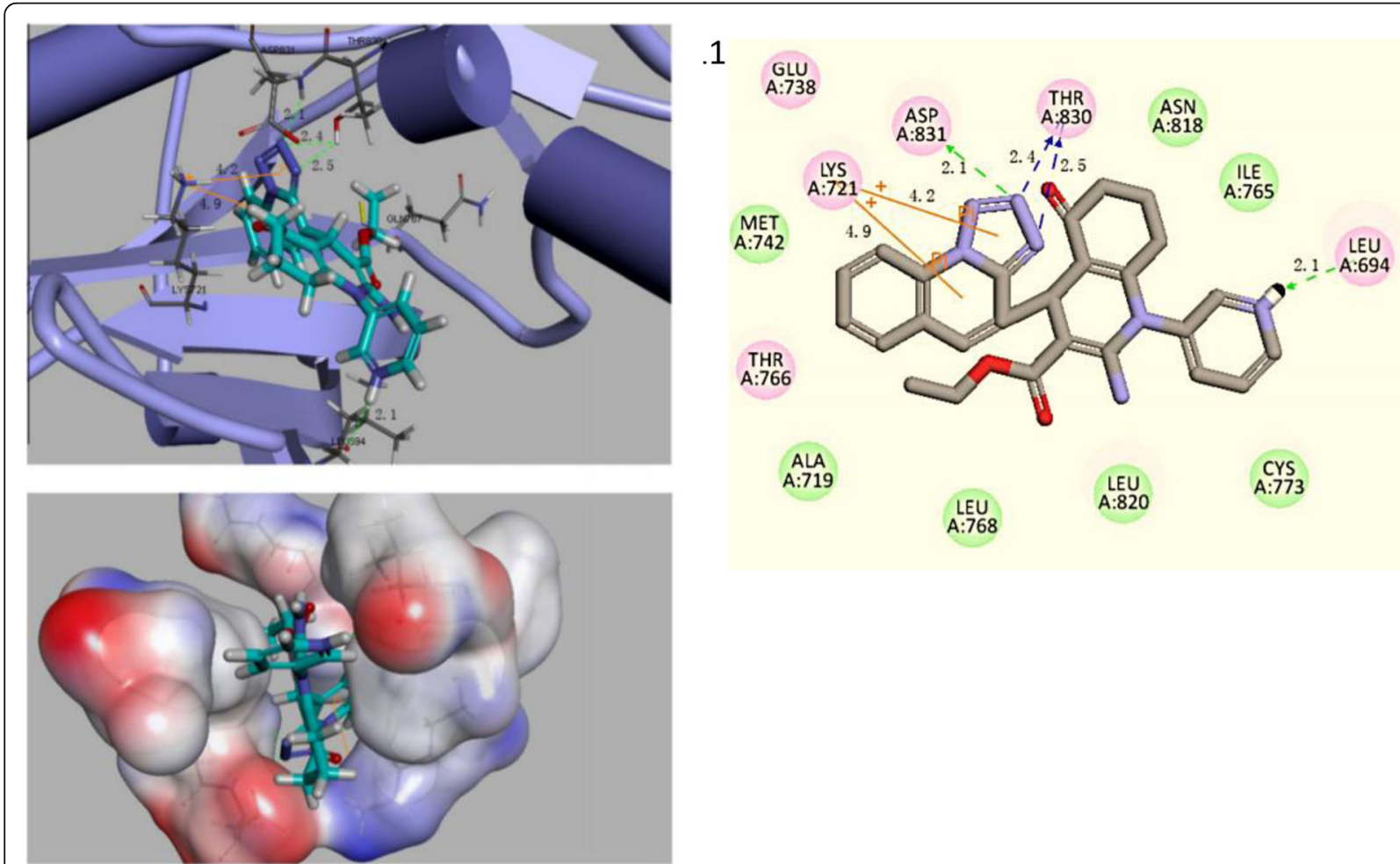

Fig. $\mathbf{7}$ a, b 2D and 3D binding model of compound 11 into the active pocket of EGFR [28] 
most potent at a sub micromolar level against breast cancer cell line $\left(\mathrm{IC}_{50}=0.63 \mu \mathrm{M}\right)$, and in addition, it exhibits an optimum pharmacokinetic profile and druglikeness. Indeed, a molecular docking study was carried out to show the most compound that has binding affinity and to test the selectivity against CDK2/4 and 6 . The native ligand (T3C) and the multi-kinase inhibitor sorafenib as a reference compound used to compare them with the results of docking [30].

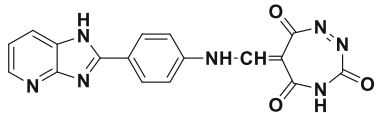

12

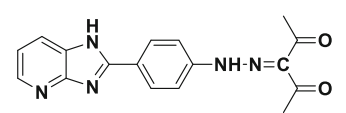

13
The tested compounds had anticancer activity and CDK9 inhibitor. Different substitutions in the Ar1 group cause the behaviour of newly synthesised compounds to change. The different modifications revealed on the SAR scheme (Fig. 8).

\section{Pyridines as PIM-1 kinase inhibitors}

PIM kinases are serine/threonine kinases. They have three subtypes: PIM-1, PIM-2, and PIM-3. PIM-1 kinase is linked with many cellular functions like proliferation, differentiation, survival, and apoptosis. Also, it has a role on progression and initiation of some types of cancer such as lymphomas, leukaemia, and solid tumours such as prostate, pancreas, and colon [32]. So, inhibition of PIM-1 kinase is an important target for the treatment of malignancies. In 2018, Abdelaziz et al. synthesised novel pyridine and thieno[2,3-b] pyridine series with diversified inhibition activity. The results gained from IC50 values, SAR studies, and docking studies conclude that the most active compound was 14 with $\mathrm{IC}_{50} 0.019 \mu \mathrm{M}$ which substituted with hydrophilic at 4-position and 2-hydroxy-5-methoxyphenyl at 6-position.<smiles>Cc1cc(-c2cc(C(=O)O)ccc2O)[nH]c(=O)c1C#N</smiles>

14

\section{Pyridines acting on VEGFR}

Inhibition of receptor tyrosine kinases leads to synergistic inhibition of solid tumours. As they existent in endothelial cells (VEGFR, PDGFR), tumour cells (FGFR, PDGFR), and pericytes/smooth muscle cells. VEGFR are vascular endothelial growth factor receptors that have three subtypes [33]. They involved in angiogenesis and vasculogenesis. They can be found on surface of some normal cells and included in cell growth. Furthermore, it may be implicated in some types of cancer cells. VEGF receptor-2 (VEGFR-2) has been specified as KDR glycoprotein. It specified for the signalling pathway which taking charge of formation of new blood vessels from tumours and prosperity through supplying with oxygen and nutrients [34, 35]. This occurs when it is activated. VEGFR-2 subjected for autophosphorylation, triggering signalling pathways leading to the proliferation of endothelial cells and then angiogenesis of tumours facilitating tumour development and metastasis. Disarray of VEGF signalling through a variety of different methods has produced in angiogenesis inhibition and tumour development. In 2018, El-Naggar et al. synthesised of target pyridine-ureas derivatives that suppress VEGF R-2 and bearing potential antitumor activity [35]. The $\mathrm{IC}_{50}$ values for the inhibitory activity against VEGFR-2 of compounds 15 and 16 were $5.00 \pm 1.91$ and $5.00 \pm 1.91$, respectively.

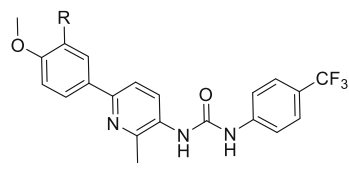

15

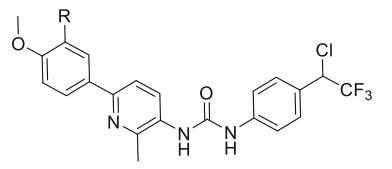

These compounds also were evaluated for their in vitro anticancer action according to National Cancer Institute $(\mathrm{NCI})$ assay protocol with mean inhibition $=43$ and 49\%, respectively. Approximately 58 cancer lines are grouped into disease subpanel growth inhibition against all from nine different cancer subtypes: leukaemia, colon, melanoma, ovarian, lung, CNS, renal, breast, and prostate cancers. They demonstrated anti-proliferative activity of all checked cancer cell lines (GI for 15; 12-78\%, GI for $16 ; 15-91 \%)$.

\section{Pyridines acting on topoisomerases}

Topoisomerases are enzymes that catalysing breaking and rejoining of phosphodiester backbone in DNA strands during the cell cycle. Currently, topoisomerase inhibitors are used in the treatment of cancer and bacterial infection. As anticancer, topoisomerase inhibitors block ligation step subsequently, leads to apoptosis and cell death as a result of producing single- and double-strand breaks which damage the whole genome. In 2019, a novel sulphur heterocyclic thiophene derivative containing 1,2 , 3 -triazole and pyridine moieties namely BTPT [2-(1-benzyl-5-methyl-1H1, 2, 3-triazol-4-yl)-6-methoxy-4-(thiophen-2-yl) pyridine]. Compound 17 was designed and synthesised as a potential human topoisomerase II $\alpha$ inhibiting anticancer agent [36]. 


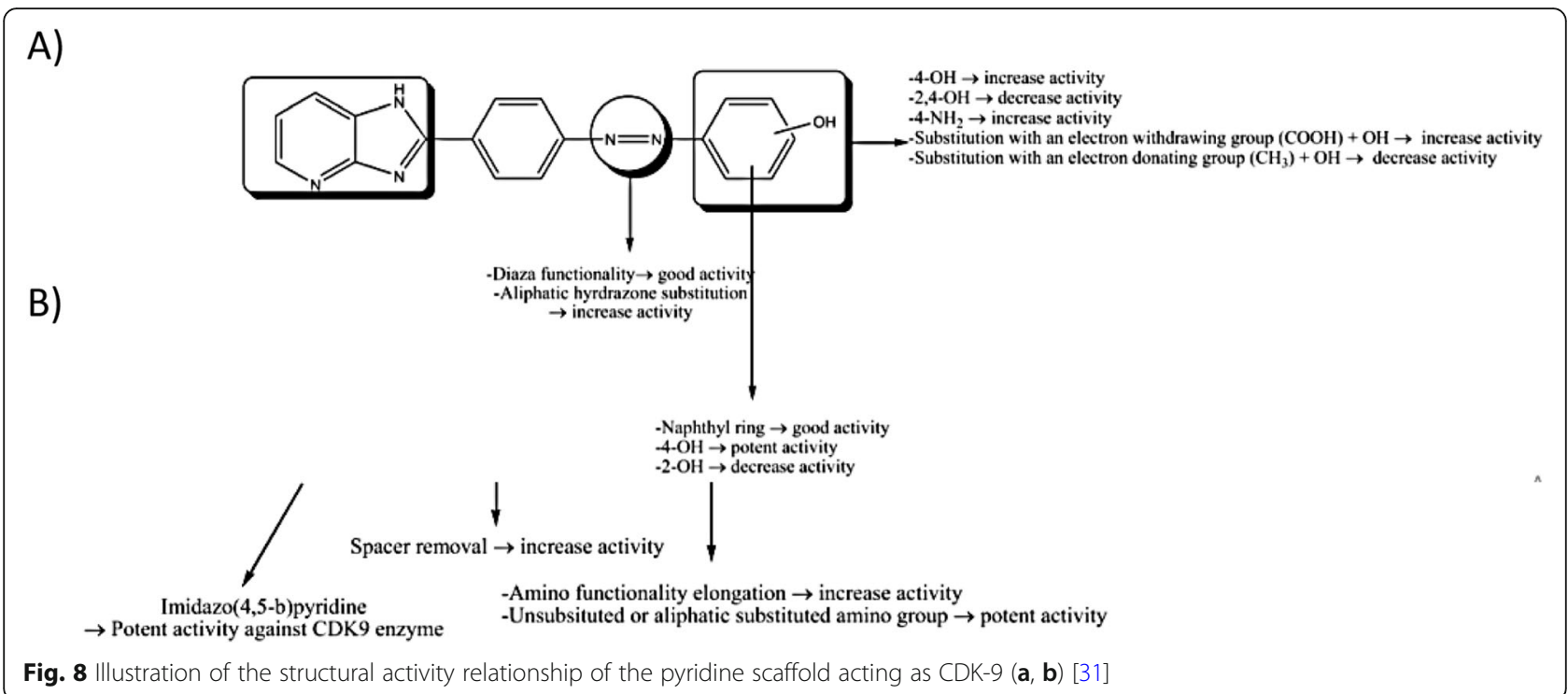<smiles>CSc1cc(-c2cccs2)cc(-c2nnn(Cc3ccccc3)c2C)n1</smiles>

17

The design of the structure was gained by singlecrystal X-ray diffraction analysis. Compound 17 elucidated cytotoxicity activity in vitro examined by MTT assay procedure against three human cancer cell lines A549, PC-3, MDAMB-231 with $\mathrm{IC}_{50}$ values of $0.68 / 0.70,1.03 / 0.77$, and $0.88 / 0.98 \mu \mathrm{M}$, respectively. In molecular docking study, the inhibitory behaviour of the title compound 17 targeting the human topoisomerase II $\alpha$ ATP binding site (PDB ID: 1ZXM) was identified. Visual analysis of docked complexes was performed by evaluating the interactions of the hydrogen bond, linking BTPT compound 17 to target site residues active in ATP Protein 1ZXM through interactions of four hydrogen acceptors and one major interaction of the $\pi$-sulphur bonds (Fig. 9).

Bahadur et al. introduced new hydroxy and chlorosubstituted 2,4-diphenyl 5H-chromeno[4,3-b]pyridines as selective topoisomerase IIa-targeting anticancer agents built on the strategy of ring expansion from constrained five-membered heterocyclic ring to more stable six-membered heterocyclic. The structure-activity relationship study for the tested compounds revealed that many compounds with 2,3,4-hydroxyphenyl group at 4position exhibited better topo IIa inhibitory activity and the antiproliferative activity than compounds containing 2,3,4-hydroxyphenyl group at 2-position of the central pyridine ring. Such findings illustrated the significance of moiety hydroxyphenyl at 4-position and chlorophenyl moiety at 2-position for exhibiting selective topo IIa inhibitory and antiproliferative activity. Compound 18 represented \% inhibition of Topo IIa $=100 \mu \mathrm{M}$.<smiles>Oc1ccc(-c2cc(-c3ccc(Cl)cc3)c3c(n2)-c2ccccc2OC3)cc1</smiles>

18

Introduction of 3 and 4 hydroxyl group is greater than the 2-hydroxyl group at 2-phenyl ring for strongly inhibiting topo IIa activity and antiproliferation. The position of chlorine substitution on 4-phenyl ring not linked with selective topo IIa inhibitory activity and antiproliferative activity. Also, the effect of ring expansion revealed that the replacement of five-membered heterocyclic ring moiety with six-membered heterocyclic ring moiety significantly impacted the topo I and IIa 


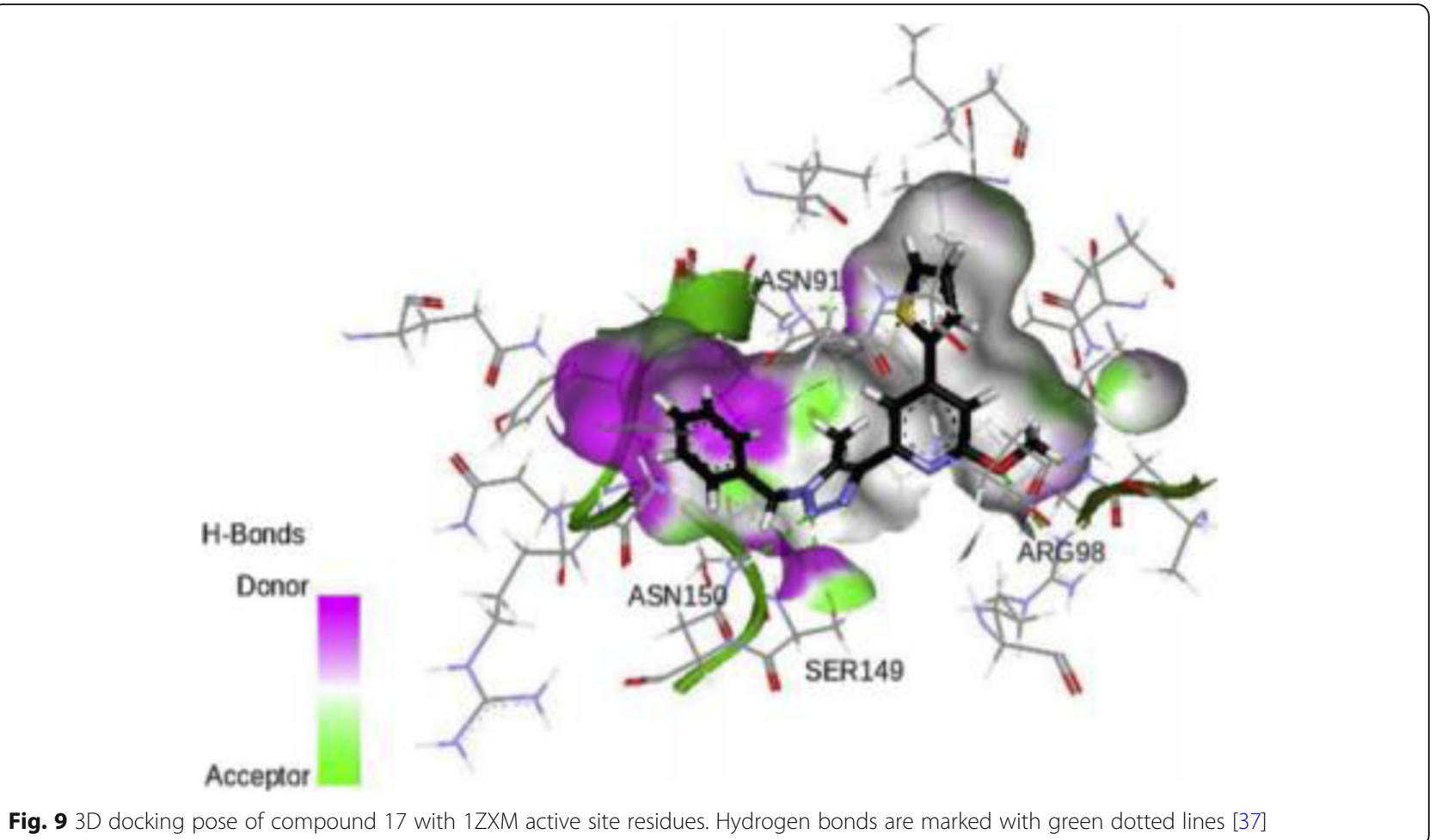

inhibitory properties of compounds [38]. The overall SAR study is shown in Fig. 10.

\section{Pyridines acting on phosphoinositide 3-kinase}

The mammalian target for the rapamycin signal transduction pathway (mTOR), the 3-kinase phosphoinositide, is included in numerous essential basic cellular functions such as cell formation, proliferation, differentiation, motility, intracellular transport, and reproduction. A family of lipid kinases and, on the basis of their classification, homology, and substrate preferences, are classified into three distinct groups (I, II, and III). In PI3Ks, it is possible to subdivide the most commonly known class I into class IA (PI3Ka, b, and d) isoforms and class IB (PI3Kg) isoforms. PI3 K activation occurred by receptor tyrosine kinases, GTPases of the Ras and Rho families, resulting in phosphorylation of PIP2 (phosphatidylinositol 4, 5-diphosphate) producing PIP3 (phosphatidylinositol 3, 4, 5-triphosphate) to the 3-hydroxyl position. Strong ones

Secondary messenger that causes various downstream effectors to be activated, including serine-threonine kinase, Akt (also known as protein kinase B or PKB [37]. One of the most mutated oncogenes is the isoform gene coding the PI3 K catalytic subunit P110a (PIK3CA) and has increased its mutation rates. This has been detected in cancers of the breast, colorectal, liver, and other types of cancer. It has been intensively targeted at this cancer pathway therapies. In 2016, Peng et al. synthesised the new 2-(2-aminopyrimidine-5-yl)-4-morpholino- $\mathrm{N}$-(pyridine-3-yl)quinazoline-7-amine sequence of $\mathrm{PI} 3 \mathrm{~K} / \mathrm{mTOR}$ inhibitors and anti-cancer activity against seven cancer cell lines were evaluated in vitro, namely PC-3, DU145, MCF-7, BT474, SK-BR-3, U937, and A431. The rational design in 2016 lead to the discovery of highly potent novel compounds of 2-(2-aminopyrimidin-5-yl)-4-morpholino-N-(pyridin-3-yl)quinazolin-7-amines compound 19 as PI3K inhibitors [39]. Moreover, compound 19 undergo further profiling against other kinases as PI3Ka, PI3K $\beta$, PI3K $\gamma$, PI3K $\delta$, mTOR9 with $\mathrm{IC}_{50} 4.2,13,64,50$, and $78 \mathrm{nM}$, respectively. Also, it has an effect on p-Akt (S473) and cell cycle.<smiles></smiles>

19

\section{Pyridines acting on maternal embryonic leucine zipper kinase (MELK)}

Maternal embryonic leucine zipper kinase (MELK) belongs to the serine-threonin family snf1/AMPK kinases involved in various cellular processes including stem cell regeneration, pre-mRNA splicing, cell proliferation, 


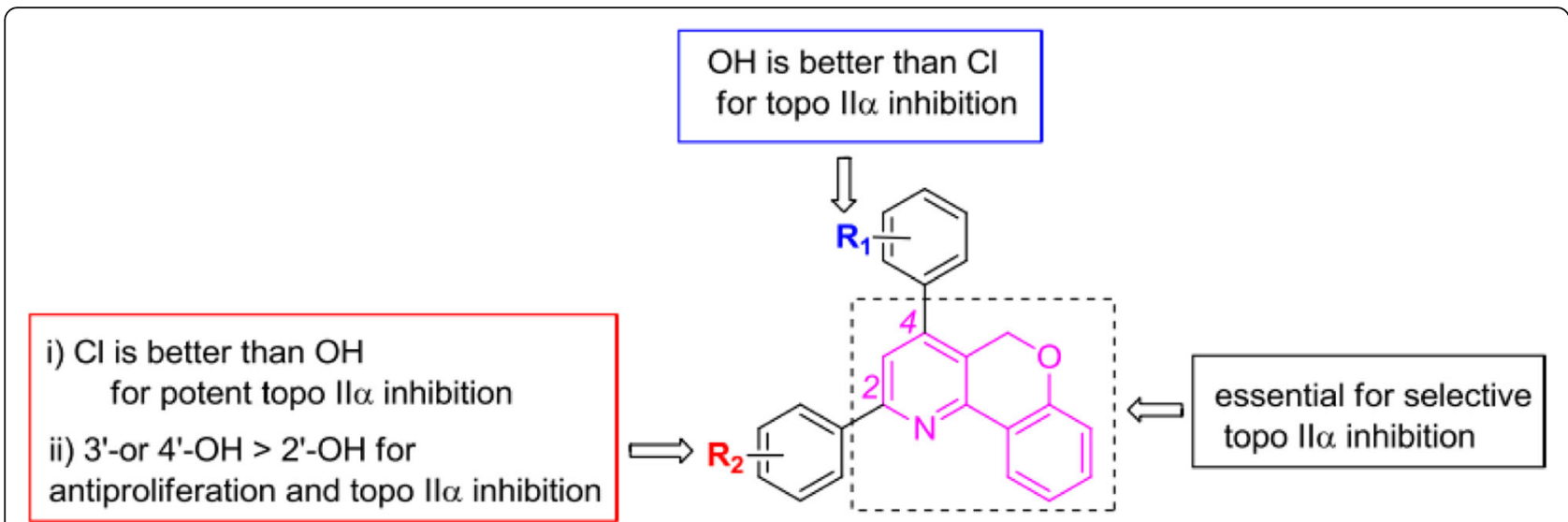

Fig. 10 Overall structure-activity relationships of hydroxy and chloro-substituted 2,4-diphenyl 5H-chromeno[4,3-b]pyridines [39]

progression of the cell cycles, and migration of cells [40, 41]. More specifically, MELK's overstatement diverse human cancers have been identified and are associated with more severe forms of astrocytoma [42], melanoma [43-45], cancer in the breast [46], and glioblastoma [47]. Increased MELK expression is also correlated to the pathological grade and expression rates of brain tumours [48] are significantly associated with poor prognosis cancer patients of prostate, breast, and glioblastoma. This has been demonstrated in several studies. Systems that have MELK-mediated/shRNA knockdown contribute to decreased viability of the liver, colon, breast, and pancreas. In 2019, Wanga et al. designed, synthesised, and evaluated for in vitro biological activities against maternal embryonic leucine zipper kinase (MELK) [47], a family of 3-substituted $1 \mathrm{H}$-pyrrolo[2,3-b]pyridine derivatives. With IC50 values ranging between 122 and $558 \mathrm{nM}$, compound 20 demonstrated moderate potency against MELK. Compound 21 displayed strong enzyme inhibition $\left(\mathrm{IC}_{50}=32 \mathrm{nM}\right)$ and excellent antiproliferative effects on A549, MDA-MB-231, and MCF-7 cell lines with $\mathrm{IC}_{50}$ values from 0.109 to $0.245 \mu \mathrm{M}$. Flow cytometry tests showed that promoted apoptosis of A549 cells in a dose-dependent manner and effectively arrested A549 cells in the G0/G1 phase. Also, it potently decreases the migration of A549 cells, had fair stable liver microsomes in rats and shows moderate inhibitory activity against different cytochrome P450 subtypes.<smiles>O=C(Nc1cc(-c2c[nH]c3ncccc23)ccn1)c1ccccc1</smiles>

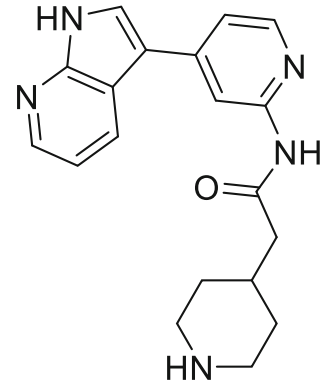

21
Moreover, compound 21 is a multi-target kinase inhibitor. Molecular modelling study was achieved, it was used for generation of images, and for potential binding mode data, the $1 \mathrm{H}$-pyrrolo[2,3b]pyridine scaffold establishes two hydrogen bonds with the $\mathrm{NH}$ of Cys89 and the backbone carbonyl oxygen of Glu87 in the hinge region. A hydrogen bond with Lys40 was formed by the pyrimidine nitrogen, hydrophobic interactions between the pyrimidine ring and Ile148, Leu86, and Leu61 hydrophobic side chains. In addition, the piperidine moiety seemed to point to the solvent area via the creation of a salt bridge with Glu93 at the edge of active pocket (Fig. 11).

\section{Pyridines acting on potential cytotoxic agents and NF-KB inhibitors}

NF-egB is a class of transcriptional eukaryotic factors that are proteins. It also occurs in the cytoplasm bound to the subunit regulator $\mathrm{IjB}$ in unstimulated cells. Upon activation of these cells by external rewards or cellular signalling, the active NF-egB releases its cytoplasmic complex from external stimuli or cellular signalling, translocate and binds to DNA nuclei $[49,50]$. Cell signalling relevant to cell survival, cell differentiation, and cell growth is regulated by binding NF-xB to DNA. The disconnection from their regulators of NF-gunB proteins results in their composite activation. NF- $\mathrm{KB}$ activated is involved in various forms of carcinogenesis, for example, cancer proliferation cell, preventing apoptosis, and increasing metastatic capacity. Kamala et al. recently synthesised a new compounds of imidazo[1,2-a]pyridine linked with thiazole/thiophene motif via a keto spacer. Compound 22 had absolute NF-YB activity inhibition as determined by assay by NF- $\mathrm{kB}$ reporter with $\left(\mathrm{IC}_{50}=6.5\right.$ $\pm 0.6 \mu \mathrm{M})$. In contrast compound 23 showed $\mathrm{IC}_{50}=$ $184.58 \pm 1.47 \mu \mathrm{M}[51]$. 

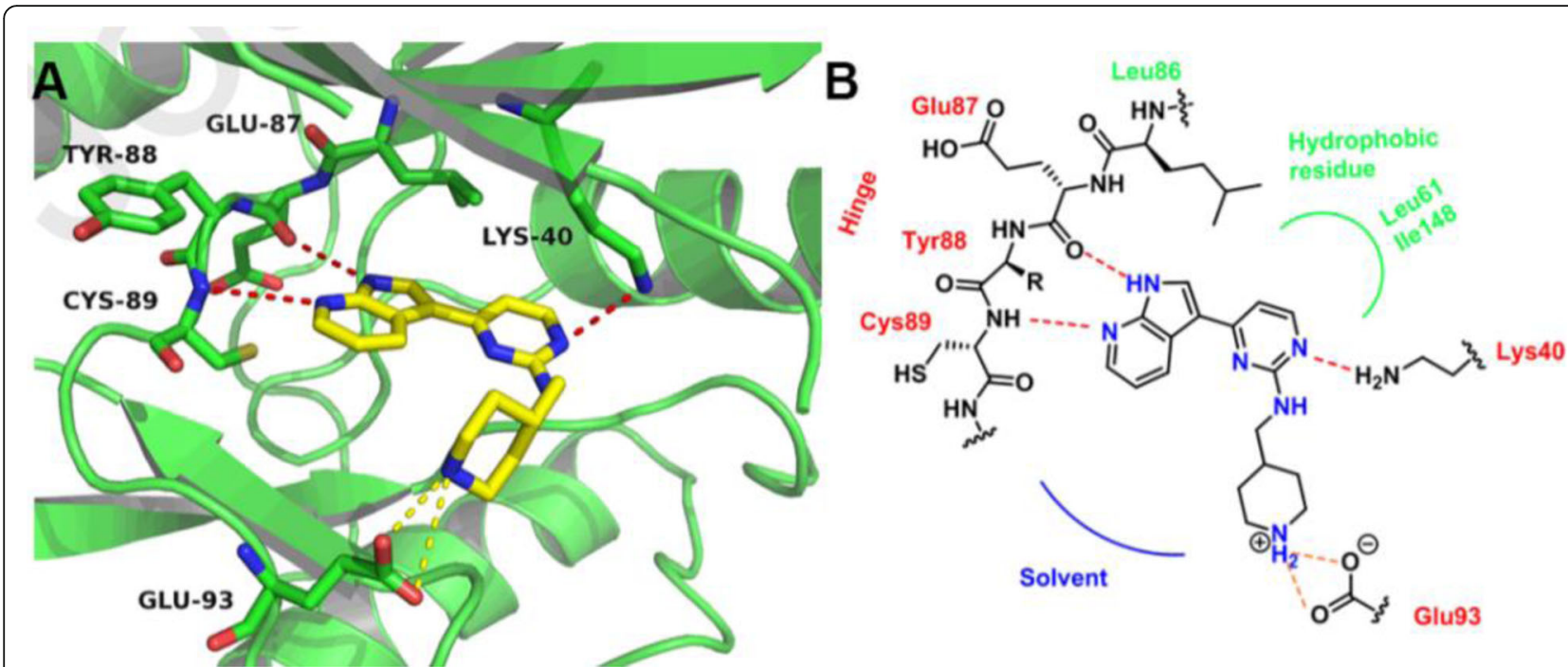

Fig. 11 Molecular docking mode of compound 21 into the MELK active site. a Detailed interactions with the protein residues. Each of the dashed red and yellow lines represent hydrogen bonds and salt bridges. $\mathbf{b}$ The two-dimensional interaction diagram showing the interaction of compound 21 with key amino acid residues in MELK active site [49]<smiles>COc1ccc(Nc2nc(N(C)C)c(C(=O)c3cnc4ccc(C)cn34)s2)cc1</smiles>

22<smiles>Cc1ccc(Nc2nc(C)c(C(=O)c3cnc4ccc(Br)cn34)s2)cc1</smiles>

\section{Conclusion}

Pyridine moiety is present in several compounds representing numerous biological activities such as antiviral, antimicrobial, and anticancer. This review investigated the role pyridine scaffold as an anticancer agent that performs on carbonic anhydrase inhibitors, ROS1 inhibitors, ALK inhibitors, C-met, EGFR, HER-2 kinase, CDK, PIM-1 kinase, VEGFR, topoisomerases, phosphoinositide 3-kinase, maternal embryonic leucine zipper kinase, and potential cytotoxic agents. This review will facilitate the design and synthesis of novel prospects for drugs used as anticancer.

\section{Abbreviations}

CA: Carbonic anhydrase; RCM: Ring-closing olefin metastasis; CDK: Cyclindependent kinase; c-Met: c-Met proto-oncogene; HER: Human epidermal growth factor receptor; EGFR: Epidermal growth factor receptor; FGFRs: Fibroblast growth factor receptor; PDGFR: Platelet-derived growth factor receptor; PI3K: Phosphoinositide 3-kinase; SAR: Structure-activity relationship; VEGFR: Vascular endothelial growth factor receptor; ALK: Anaplastic lymphoma kinase protein; MELK: Maternal embryonic leucine zipper kinase; NCl: National Cancer Institution; PIP: Phosphatidylinositol; $\mathrm{Mn}(\mathrm{acac})_{3}$ : Manganese acetylacetonate

\section{Acknowledgements}

The authors acknowledge Al-Azhar University in Egypt and Future University in Egypt for facilitating web review for collecting the required data.

\section{Authors' contributions}

All authors have read and approved the manuscript. E.A. collected all the data and wrote the review. N.S. prepared all figures and participated in

writing the review. M.H. revised the methods and references section. H.R. revised the whole review and updated it.

\section{Funding \\ No funding \\ Availability of data and materials \\ Not applicable (Review Article)}

Ethics approval and consent to participate

Not applicable

\section{Consent for publication}

Not applicable

\section{Competing interests}

The authors declare they have no competing interest regarding this review.

\section{Author details}

${ }^{1}$ Faculty of Pharmaceutical Sciences and Pharmaceutical Industries, Department of Pharmaceutical Chemistry, Future University in Egypt, Cairo, Egypt. ${ }^{2}$ Faculty of Pharmacy, Department of Pharmaceutical Chemistry, Ain Shams University, Abbasia, Cairo, Egypt. ${ }^{3}$ Faculty of Pharmacy, Department of Pharmaceutical Chemistry, Al-Azhar University, Nasr City, Cairo, Egypt.

Received: 18 October 2020 Accepted: 21 December 2020

Published online: 18 January 2021

\section{References}

1. Nicolaou KC, Scarpelli R, Bollbuck B, Werschkun B, MAPereira M, Wartmann $M$ et al (2000) Chemical synthesis and biological properties of pyridine epothilones. Chem Biol 7:593-599

2. Ferlay J, Soerjomataram I, Ervik M, Dikshit R, Eser S, Mathers C (2012) Cancer incidence and mortality worldwide: sources, methods and major patterns in GLOBOCAN. Int J Cancer 136(5):E359-E386. https://doi.org/10.1002/ijc.29210

3. Safo MK, Moure CM, Burnett JC, Joshi GS, Abraham DJ (2001) Highresolution crystal structure of deoxy hemoglobin complexed with a potent allosteric effector. Protein Sci 10:951-957. https://doi.org/10.1110/ps.50601

4. Xi L, Zhang R, Liang S, Chen S, and. Yu X. (2014) Copper-catalyzed aerobic synthesis of 2-arylpyridines. Org Lett 16(20):5269-5271

5. Andersson H, Almqvist F, Olsson R (2007) Synthesis of 2-substituted pyridines via a regioselective alkylation, alkynylation and arylation of pyridine N-oxides. Org Lett 9(7):1335-1337 
6. Aldenderfer M, Craig NM, Speak RJ, Filcoff RP (2008) Four-thousand-year-old gold artifacts from the Lake Titicaca basin, southern Peru. Proc Natl Acad Sci U S A 105(13):5002-5005

7. Gati W, Rammah MM, Rammah MB, Couty F, Evano G (2012) De novo synthesis of 1,4-dihydropyridines and pyridines. J Am Chem Soc 134:90789081. https://doi.org/10.1021/ja303002a

8. Scherbinina SI, Fedorov OV, Levin W, Kokorekin VA, Struchkova MI, Dilman AD (2017) Synthesis of 3-fluoropyridines via photoredox-mediated coupling of a,a-difluoro- $\beta$-iodoketones with silyl enol ethers. J Org Chem 82:1296712974. https://doi.org/10.1021/acs.joc.7b02467

9. Yoshida K, Kawagoe F, Hayashi K, Horiuchi S, Imamoto T (2009) Synthesis of 3-hydroxypyridines using ruthenium-catalyzed ring-closing olefin metathesis. Org Lett 11:515-518

10. Shen J, Cai D, Kuai C, Liu Y, Wei M, Cheng G, Cui X (2015) Base-promoted $\beta$ $\mathrm{C}(\mathrm{sp} 3)-\mathrm{H}$ functionalization of enaminones: an approach to polysubstituted pyridines. J Org Chem 13:6584-6589. https://doi.org/10.1021/acs.joc. 5 b00635

11. Wang Y, Chiba S, Narasaka K (2008) Mn(III)-catalyzed synthesis of pyrroles from vinyl azides and 1,3-dicarbonyl compounds. Organic Letters 10:50195022. PMID 18842053. https://doi.org/10.1021/ol802120u

12. Huang H, Cai J, Tang L, Wang Z, Li, F.andDeng G. (2016) Metal-free assembly of polysubstituted pyridines from oximes and acroleins. Org Chem 81(4):1499-1505. https://doi.org/10.1021/acs.joc.5b02624

13. Maruyama IN (2014) Mechanisms of activation of receptor tyrosine kinases: monomers or dimers. cells:304-330. https://doi.org/10.3390/cells3020304

14. Badger MR, Palmqvist K, Yu JW (1994) Measurement of CO2 and HCO3fluxes in cyanobacteria and microalgae during steady-state. photosynthesis 90(3):529-536. https://doi.org/10.1111/j.1399-3054

15. Pastorekova S, Gillies RJ (2019) The role of carbonic anhydrase IX in cancer development: links to hypoxia, acidosis, and beyond. Cancer Metastasis Rev 38(1-2):65-77. https://doi.org/10.1007/s10555-019-09799-0

16. Alafeefy AM, Ahmad R, Abdulla M, Eldehna WM, Al-Tamimi AM, Abdel-Aziz HA et al (2016) Development of certain new 2-substituted-quinazolin-4-ylaminobenzenesulfonamide as potential antitumor agents carbonic anhydrase inhibitors. Eur J Med Chem 109:247-253

17. Ansari MF, Idrees D, Hassan Ml, Ahmad K, Avecilla F, Azam A (2017) Design, synthesis and biological evaluation of novel pyridine-thiazolidinone derivatives as anticancer agents: targeting human carbonic anhydrase IX. Eur J Med Chem 144:544-556. https://doi.org/10.1016/j.ejmech.2017.12.049

18. Peerzada MN, Khan P, Ahmad K, Hassan MI, Azam A (2018) Synthesis, characterization and biological evaluation of tertiary sulfonamide derivatives of pyridyl-indole based heteroaryl chalcone as potential carbonic anhydrase IX inhibitors and anticancer agents. Eur J Med Chem 155:13-23. https://doi. org/10.1016/j.ejmech.2018.05.034

19. Tian Y, Zhang T, Long I., Li Z., Wan S., Wang G, et al. (2018) Design, synthesis, biological evaluation and molecular modeling of novel 2-amino4-(1-phenylethoxy) pyridine derivatives as potential ROS1 inhibitors. Eur J Med Chem 143:182-199. https://doi.org/10.1016/j.ejmech.2017.11.002

20. Liu S, Jiang Y, Yan R, Li S, Wan S, Zhang T et al (2019) European Journal of Medicinal Chemistry Design, synthesis and biological evaluations of 2amino-4-(1-piperidine) pyridine derivatives as novel anti crizotinib-resistant ALK/ROS1 dual inhibitors. Eur J Med Chem 179:358-375. https://doi.org/10. 1016/j.ejmech.2019.06.043

21. Zhao Y, Zhang J, Zhuang R, He R, Xi J, Pan X et al (2017) Synthesis and evaluation of a series of pyridine and pyrimidine derivatives as type II c-Met inhibitors. Bioorganic Med Chem 25(12):3195-3205. https://doi.org/10.1016/j. bmc.2017.04.003

22. Bottaro DP, Rubin JS, Faletto DL, Chan AM, Kmiecik TE, Vande GF et al (1991) Identification of the hepatocyte growth factor receptor as the c-met proto-oncogene product. Science 251:802-804. https://doi.org/10.1126/ science. 1846706

23. Wang W, Xu S, Duan Y, Liu X, Li X, Wang C et al (2018) Synthesis and bioevaluation and doking study of $1 \mathrm{H}$-pyrrolo[2,3-b]pyridine derivatives bearing aromatic hydrazone moiety as c-Met inhibitors. Eur. J. Med. Chem. 145:315-327. https://doi.org/10.1016/j.ejmech.2017.12.078

24. Yun CH, Boggon TJ, Li Y, Woo MS, Greulich H, Eck Mj (2007) Structures of Lung Cancer-Derived EGFR Mutants and Inhibitor Complexes : Mechanism of Activation and Insights into Differential Inhibitor Sensitivity. Cancer Cell 11(3):217-227. https://doi.org/10.1016/j.ccr.2006.12.017

25. Günther M, Laux J, Laufer S (2019) Synthesis and structure-activityrelationship of 3,4-Diaryl-1H-pyrrolo[2,3-b]pyridines as irreversible Inhibitors of mutant EGFR-L858R/T790M. Eur J Pharm Sci 128:91-96. https://doi.org/10. 1016/j.ejps.2018.11.021

26. Advani RH, Buggy JJ, Sharman JP, Smith SM, Boyd TE, Grant B et al (2013) Bruton tyrosine kinase inhibitor ibrutinib (PCI-32765) has significant activity in patients with relapsed/refractory B-cell malignancies. J. Clin. Oncol. 31(1): 88-94. https://doi.org/10.1200/JCO.2012.42.7906

27. Sangani CB, Makawana JA, Duan YT, Teraiya SB, Thumar NJ, Zhu HL et al (2014) Design, synthesis and molecular modeling of biquinoline-pyridine hybrids as a new class of potential EGFR and HER-2 kinase inhibitors. Bioorganic Med Chem Lett 24:4472-4476. https://doi.org/10.1016/j.bmcl. 2014.07.094

28. Asghar U, Witkiewicz AK, Turner NC, Knudsen ES (2015) The history and future of targeting cyclin-dependent kinases in cancer therapy. Nat. Rev. Drug Discov. 14:130-146. https://doi.org/10.1038/nrd4504

29. Rahaman MH, Kumarasiri M, Mekonnen LB, Yu M, Diab S, Albrecht $\mathrm{H}$ et al (2016) Targeting CDK9: a promising therapeutic opportunity in prostate cancer. Endocr Relat Cancer 23:T211-T226. https://doi.org/10.1530/ERC-160299

30. Ghanem NM, Farouk F, George RF, Abbas SES, El-Badry OM (2018) Design and synthesis of novel imidazo[4,5-b]pyridine based compounds as potent anticancer agents with CDK9 inhibitory activity. Bioorg. Chem. 80:565-576. https://doi.org/10.1016/j.bioorg.2018.07.006

31. Holmes K, Roberts OL, Thomas AM, Cross MJ (2007) Vascular endothelia growth factor receptor-2: structure, function, intracellular signalling and therapeutic inhibition, Cell. Signal 1:2003-2012. https://doi.org/10.1016/j. cellsig.2007.05.013

32. Mori M, Tintori C, Christopher RSA, Radi M, Schenone S, Musumeci F et al (2013) A combination strategy to inhibit Pim-1: synergism between noncompetitive and ATP-competitive inhibitors. Chem Med Chem 8:484496. https://doi.org/10.1002/cmdc.201200480

33. Fan TPD, Jagger R, Bicknell R (1995) Controlling the vasculature: angiogenesis, anti-angiogenesis and vascular targeting of gene therapy. Trends Pharmacol Sci 16:57-66. https://doi.org/10.1016/S01656147(00)88979-8

34. Folkman J (1995) Angiogenesis in cancer, vascular, rheumatoid and other disease. Nat. Med. 1:27-30. https://doi.org/10.1038/nm0195-27

35. El-Naggar M, Almahli H, Ibrahim HS, Eldehna WM, Abdel-Aziz HA (2018) Pyridine-ureas as potential anticancer agents: Synthesis and in vitro biological evaluation. Molecules 23:1459. https://doi.org/10.3390/ molecules23061459

36. Murugavel S, Ravikumar C, Jaabil G, Alagusundaram P (2019) Synthesis, computational quantum chemical study, in silico ADMET and molecular docking analysis, in vitro biological evaluation of a novel sulfur heterocyclic thiophene derivative containing 1,2, 3-triazole and pyridine moieties as a potential human. Comput Biol Chem 79:73-82. https://doi.org/10.1016/j.compbiolchem.2019.01.013

37. Liu P, Cheng H, Roberts TM, Zhao JJ (2009) Targeting the phosphoinositide 3-kinase pathway in cancer. Nat Rev Drug Discov 8:627-644. https:/doi.org/ 10.1038/nrd2926

38. Magar TT, Seo SH, Kadayat TM, Jo H, Shrestha A, Bist G et al (2018) Synthesis and SAR study of new hydroxy and chloro-substituted 2,4-diphenyl 5Hchromeno[4,3-b]pyridines as selective topoisomerase lla-targeting anticancer agents. Bioorganic Med Chem 8:1909-1919. https://doi.org/10. 1016/j.bmc.2018.02.035

39. Peng W, Tu Z, Long Z, Liu Q, Lu G (2016) Discovery of 2-(2-aminopyrimidin5-yl)-4-morpholino-N-(pyridin-3-yl) quinazolin-7-amines as novel PI3K/mTOR inhibitors and anticancer agents. Eur J Med Chem 108:644-654. https://doi. org/10.1016/j.ejmech.2015.11.038

40. Jung $\mathrm{H}$, Seong $\mathrm{HA}, \mathrm{Ha} H$ (2008) Murine protein serine/threonine kinase 38 activates apoptosis signal-regulating kinase 1 via Thr 838 phosphorylation. J Biol Chem 283(50):34541-34553

41. Wang Y, Begley M, Li q., Huang H.T., Lako A., Eck M.J., et al. (2016) Mitotic MELK-elF4B signaling controls protein synthesis and tumor cell survival. PNAS 113(35):9810-9815. https://doi.org/10.1073/pnas.1606862113

42. Marie SK, Okamoto OK, Uno M, Hasegawa AP, Obashinjo SM, Cohen T, Camargo AA et al (2010) Maternal embryonic leucine zipper kinase transcript abundance correlates with malignancy grade in human astrocytomas. Int J Cancer 122:807-815

43. Ryu B, Kim DS, DeLuca AM, Alani RM (2007) Comprehensive expression profiling of tumor cell lines identifies molecular signatures of melanoma progression. PLoS One 2(7):e594. https://doi.org/10.1371/ journal.pone.0000594 
44. Janostiak R, Rauniyar N, Lam TL, Ou J, Zhu LJ, Green MR et al (2017) MELK Promotes Melanoma Growth by Stimulating the NF-kB Pathway. Cell Rep. 21:2829-2841. https://doi.org/10.1016/j.celrep.2017.11.033

45. Speers C, Zhao SG, Kothari V, Santola A, Liu M, Romans KW et al (2016) Maternal embryonic leucine zipper kinase (MELK) as a novel mediator and biomarker of radioresistance in human breast cancer. Clin Cancer Res 22: 5864-5875. https://doi.org/10.1158/1078-0432.CCR-15-2711

46. Cenk K, Monique B, Lijs B, Aleyde VE, Linders JT, Dirk B, Mathieu B (2013) Maternal embryonic leucine zipper kinase (MELK) reduces replication stress in glioblastoma cells. J Biol Chem 288:24200-24212

47. Wang R, Chen Y, Yang B, Yu S, Zhao X (2019) Design, synthesis, biological evaluation and molecular modeling of novel $1 \mathrm{H}$-pyrrolo[2,3-b]pyridine derivatives as potential anti-tumor agents. Bioorg Chem 94:103474. https:// doi.org/10.1016/j.bioorg.2019.103474

48. Nakano I, Masterman SM, Saigusa K, Paucar AA, Horvath S, Shoemaker L et al (2010) Maternal embryonic leucine zipper kinase is a key regulator of the proliferation of malignant brain tumors, including brain tumor stem cells. J Neurosci Res 86:48-60

49. Gilmore TD (2006) Introduction to NF-kappaB: players, pathways, perspectives. Oncogene 25(51):6680-6684. https://doi.org/10.1038/sj.onc. 1209954

50. Siebenlist U, Franzoso G, Brown K (1994) Structure, regulation and function of NF-kappa B. Annu Rev Cell Biol 10:405-455. https://doi.org/10.1146/ annurev.cb.10.110194.002201

51. Vasu KK, Digwal CS, Pandya AN, Pandya DH, Sharma JA, Pateet S, al. (2017) Imidazo[1,2-a]pyridines linked with thiazoles/thiophene motif through keto spacer as potential cytotoxic agents and NF-KB inhibitors. Bioorg Med Chem Lett 27:5463-5466. https://doi.org/10.1016/j.bmcl.2017.10.060

\section{Publisher's Note}

Springer Nature remains neutral with regard to jurisdictional claims in published maps and institutional affiliations.

\section{Submit your manuscript to a SpringerOpen ${ }^{\circ}$ journal and benefit from:}

- Convenient online submission

- Rigorous peer review

- Open access: articles freely available online

High visibility within the field

- Retaining the copyright to your article

Submit your next manuscript at $\boldsymbol{\nabla}$ springeropen.com 